\section{PC-149＼cjkstart単独行動への躊躇と社会的問題につ いての思考力の関係}

○林 幹也 $^{1}$

(明星大学)

キーワード：批判的思考, 集団意思決定, 社会的問題

一般的に言って，集団での行動の際には，自らがリーダーとならない 限りは行動に必要な意思決定を他者に委ねることが可能であるため, 単 独行動に比べれば個人として意思決定を行う機会は減少すると思われる。 それゆえ, 単独行動を躊躇する人々は, 単独行動を好む（あるいは躊躇 しない）人々に比べて，様々な問題に対する思考力に乏しい可能性があ るのではないかと考えた。そこで本研究は20代から50代までの回答者に 対して，林・竹村・井出野（2017）の命題評価課題を使用して社会問題 への思考力を測定するとともに，単独行動に対する躊躇（およびその他 の集団行動・単独行動に関連する特性）をリッカート尺度によって測定 し，それらの相関関係を検討した $(\mathrm{N}=416)$ 。その結果，本研究の予想 に一致して, 単独行動への躊躇が強いほど, 社会問題についての思考力 が低いことが明らかになった $(\mathrm{r}=-.17, \mathrm{p}<.001)$ 。同様に，孤独に対し て否定的な態度を持っているほど, 社会問題についての思考力が低いこ とが明らかになった $(\mathrm{r}=-.19, \mathrm{p}<.001)$ 。しかしながら以上の相関関倸 は比較的弱く，変数間の関係に影響を及ぼす調整変数の検討が必要であ ることが明らかになった。

連絡先 E-mail : hayashim@psy.meisei-u.ac.jp

\section{PC-151日本の青年期女性における自己愛と ファーストネームイレイズム}

○津田 恭充 ${ }^{1}$

(1関西福祉科学大学)

自分を指すときに一人称単数代名詞の代わりに自分の名前を使うこと がある。これはイレイズム (illeism) と呼ばれ幼児期では一般的な現象 である。青年期以降では，欧米では名声をもった人物（特に男性）が公 的場面でまれにイレイズムを使用する程度であるが，日本では女性が私 的場面で頻繁に用いる。また，欧米ではフルネームやラストネームを用 いるが，日本では主にファーストネームを用いるという違いがある。こ うした特徴をもった現象を表す述語はないため, ここではこれをファー ストネームイレイズム（以下，FMI と略す）と呼ぶことにする。本研究 では FMI は自己愛を反映していると仮定した。研究参加者は175名の女 子大学生で, 顕在的自尊心 (山本ら, 1982), 潜在的自尊心 (Single-Target IAT; Karpinski \& Steinman, 2006), 日常会話で最も頻繁に使う自 称詞を測定した。Jordan, et al.（2003）にならって顕在・潜在的自尊心 の高低を組み合わせて 4 群を設け，FMI 使用者の割合を比較した。残差 分析の結果, 潜在的自尊心低・顕在的自尊心高群（自己愛的とされる群） では FMI 使用者の割合が有意に高かった $(\mathrm{p}<.001)$ 。つまり，仮説は支 持された。心理学的および言語学的観点から考察を行った。

連絡先 E-mail：hisamit2@gmail.com
PC-150

シャイネス傾向とイベント中間フィー ドバックへの感情が交際希望人数に 与える影響一スピードデーティング を用いた検討一

○西村 太志 ${ }^{1}$, 相馬 敏彦 ${ }^{2}$, 鬼頭 美江 $^{3}$, 谷口 淳一 $^{4}$, 山田 順子 ${ }^{5}$, 金政 祐司 ${ }^{6}$

( ${ }^{1}$ 広島国際大学, ${ }^{2}$ 広島大学, ${ }^{3}$ 明治学院大学, ${ }^{4}$ 帝塚山大学, ${ }^{5}$ 玉川大学, ${ }^{6}$ 追手門学院大学 $)$

キーワード：スピードデーティング，シャイネス，中間フィードバック

シャイネス傾向の強さは, 初対面の人や多くの人との対面場面での相 互作用に抑制的な影響を及ほしやすい。ではシャイネス傾向の強さは，交 際相手を実際に探す場面であるスピードデーティング（以下 SD）場面に おいて，交際希望人数を表明する場合にどのように機能するのだろうか。 また，SD イベント中に，異性から自身の印象に対する全般的な中間 フィードバック $(\mathrm{FB})$ を受けた際に生じる感情によって, この希望人数 に変化は生じるのだろうか。2019年 3 月に実施した SD イベントに参加 した参加者 40 名（男女各 10 名 $\times 2$ セッション, 平均年齢 33.8 歳, $\mathrm{SD}=$ 3.33）に対して実施したアンケートやSD イベント時の交際希望人数の データから, 以下のことが示された。まず，シャイネスは希望人数には 影響を及ぼしておらず，中間 FB 時のポジティブ感情は希望人数を増や していた。さらにシャイネスー中間 FB の交互作用効果が示され, シャ イネス傾向が低く, 中間フィードバックをポジティブにとらえていない 場合に, 希望人数が少ないことが示された。

連絡先 E-mail : t-nishim@hirokoku-u.ac.jp

\section{PC-152 人気があるからおいしく感じる一ラ ンキング情報が人々の味の評価に及} ぼす効果—

○橋本 博文 ${ }^{1}$, 前田 楓 ${ }^{2}$

('安田女子大学, ${ }^{2}$ 安田女子大学)

キーワード：期待，ランキング情報，おいしさの評価

本研究の目的は, 人々の「拈いしさ」の評価に対する期待の効果につ いて実験を通じて検討することにある。この目的をかなえるため，本研 究では, アイスクリームや技茶の人気ランキングを操作する「ききアイ ス実験」ないし「きき茶実験」を実施し，それぞれ全く同一の商品を口 にする場合でも，ランキング情報の提示によって人々の「おいしさ」の 評価が変わるか否かを分析した。女子大学生50名を対象とする実験の結 果,「ききアイス実験」においても「きき茶実験」においても，商品を口 にする前に，ランキングが上位だという情報を与えられると人々の「お いしさ」の評価は実際に上がり，反対にランキングが下位だという情報 を与えられるとその評価が下がるという傾向が顕著に示された。これら の結果は，ランキング情報の提示によって抱く人々の期待が，商品の味 や品質の判断を大きく左右することを示すものであり，おいしいから人 気が出るという過程とは逆の「人気だからおいしく感じる」過程の存在 を示す結果である。

連絡先 E-mail : hashimoto-h@yasuda-u.ac.jp 